\title{
Protocol
}

\section{Flow Cytometric Analysis of Xenopus Immune Cells}

\author{
Eva-Stina Edholm ${ }^{1}$ \\ Department of Microbiology and Immunology, University of Rochester Medical Center, Rochester, \\ New York 14620
}

Flow cytometry is a versatile analytical platform capable of multiparameter analysis of more than a thousand individual cells per second. This technique is used to measure the physical and chemical characteristics of individual cells in a heterogeneous cell suspension as they pass through one or multiple lasers. Physical properties, such as size and internal complexity, are recorded as light scattering at different angles and are expressed as forward- and side-scatter, respectively. Following light excitation, fluorochromes conjugated to antibodies or intercalated with different cellular components reemit light at distinct wavelengths. This can identify a broad array of cell specific antigens, further defining distinct cell subsets based on activation, lineage, and developmental stage. The combination of labels that can be used depends on the laser used to excite the fluorochromes and on the detector and available antibodies. With the growing number of Xenopus-specific antibodies, flow cytometry can be used to identify, isolate, and characterize distinct immune cell subsets. In this protocol, different methods to obtain single-cell suspensions from various $X$. laevis tissues are described. A standard three-parameter procedure defining viability and two cell-surface markers is then described.

It is essential that you consult the appropriate Material Safety Data Sheets and your institution's Environmental Health and Safety Office for proper handling of equipment and hazardous materials used in this protocol.

RECIPES: Please see the end of this protocol for recipes indicated by $<R>$. Additional recipes can be found online at http://cshprotocols.cshlp.org/site/recipes.

Reagents

Amphibian phosphate-buffered saline (APBS) $<\mathrm{R}>$

Anti-Xenopus monoclonal antibodies

Anti-Xenopus antibodies can be found at the Xenopus laevis Research Resource for Immunobiology: https:// www.urmc.rochester.edu/microbiology-immunology/xenopus-laevis.aspx.

Enzyme(s) for tissue disruption (e.g., collagenase) (optional; see Step 16)

Flow cytometry staining buffer $(\mathrm{FCSB})<\mathrm{R}>$

Fluorochrome-conjugated secondary antibodies

Fluorochrome-conjugated streptavidin

Ice

Percoll ( $1.130 \pm 0.005 \mathrm{~g} / \mathrm{mL}$ in sterile APBS) (optional; see Step 4)

Propidium iodide $(1 \mathrm{mg} / \mathrm{mL}$ in molecular grade water)

\footnotetext{
${ }^{1}$ Correspondence: eva-stina.i.edholm@uit.no

From the Xenopus collection, edited by Hazel L. Sive.

(c) 2018 Cold Spring Harbor Laboratory Press

Cite this protocol as Cold Spring Harb Protoc; doi:10.1101/pdb.prot097600
} 


\section{Equipment}

Sodium heparin (1000 U/mL) (optional; see Step 3)

Trypan blue

Xenopus laevis adults

Cell strainer (optional; see Step 16)

Centrifuge (benchtop, refrigerated, with swinging bucket rotors for 5- and 15-mL tubes)

Compound microscope

Dissection kit (optional; see Steps 10, 14)

FACS tubes ( $5 \mathrm{~mL}$, round-bottom, polystyrene)

Flow cytometer

A number of different flow cytometry instruments are available, ranging in capability from a single to $>18$ different detectors. Due to the limited number of frog-specific antibodies currently available we find that a personal benchtop flow cytometer with two lasers (typically blue and red), two light scatter detectors and four fluorescence detectors with optical filters optimized for the detection of popular fluorochromes is sufficient.

Hemocytometer

Ice bucket

Microcentrifuge

Microcentrifuge tubes (1.5-mL, flip-top)

Petri dish $(35 \times 10 \mathrm{~mm})$ (optional; see Step 11)

Polyester mesh $(70-\mu \mathrm{m} ; 28 \%$ open area) (optional; see Step 11)

Scalpel blade (optional; see Step 15)

Tubes (15-mL, conical)

Tweezers (small, micro-mashing with $1 / 4$ inch $\times 1 \frac{1}{2}$ inch pads; part \# MASMIC from Arrow Springs) (optional; see Step 11)

\section{METHOD}

Preparation of Cells from Adult X. laevis

\section{Isolation of Peritoneal Leukocytes}

An example of a scatter profile for peritoneal leucocytes is shown in Figure $1 B$.

1. Collect peritoneal leukocytes as described in Protocol: Elicitation of Xenopus laevis Tadpole and Adult Frog Peritoneal Leukocytes (Grayfer 2018).

2. Perform a cell count and viability analysis using a hemocytometer and trypan blue exclusion: Prepare a $0.4 \%$ solution of trypan blue in APBS ( $\mathrm{pH} 7.3$ ). Add $10 \mu \mathrm{L}$ of trypan blue solution to a $10-\mu \mathrm{L}$ cell suspension. Load onto a hemocytometer and count the cells.

Cells that have taken up trypan blue are nonviable.

\section{Isolation of Blood Leukocytes}

3. Collect $1-2 \mathrm{~mL}$ of blood in APBS containing $50 \mathrm{U} / \mathrm{mL}$ sodium heparin as anticoagulant. Adjust to a final volume of $4 \mathrm{~mL}$.

4. Add $4 \mathrm{~mL}$ of a $51 \%(\mathrm{v} / \mathrm{v})$ solution of $1.130 \pm 0.005 \mathrm{~g} / \mathrm{mL}$ Percoll stock diluted in APBS to a $15-\mathrm{mL}$ centrifuge tube. Carefully layer $4 \mathrm{~mL}$ of blood/heparin/APBS mixture on top without disturbing the Percoll layer.

5. Centrifuge at $300 \mathrm{~g}$ for $25 \mathrm{~min}$ at $4^{\circ} \mathrm{C}$.

Centrifugation over the Percoll gradient should be performed with slow acceleration and a slow or no break to prevent disruption of the interphase. 


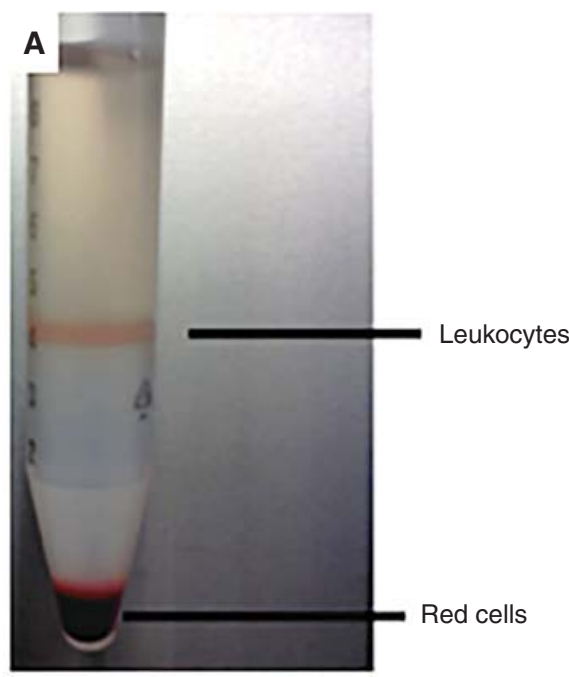

B

C
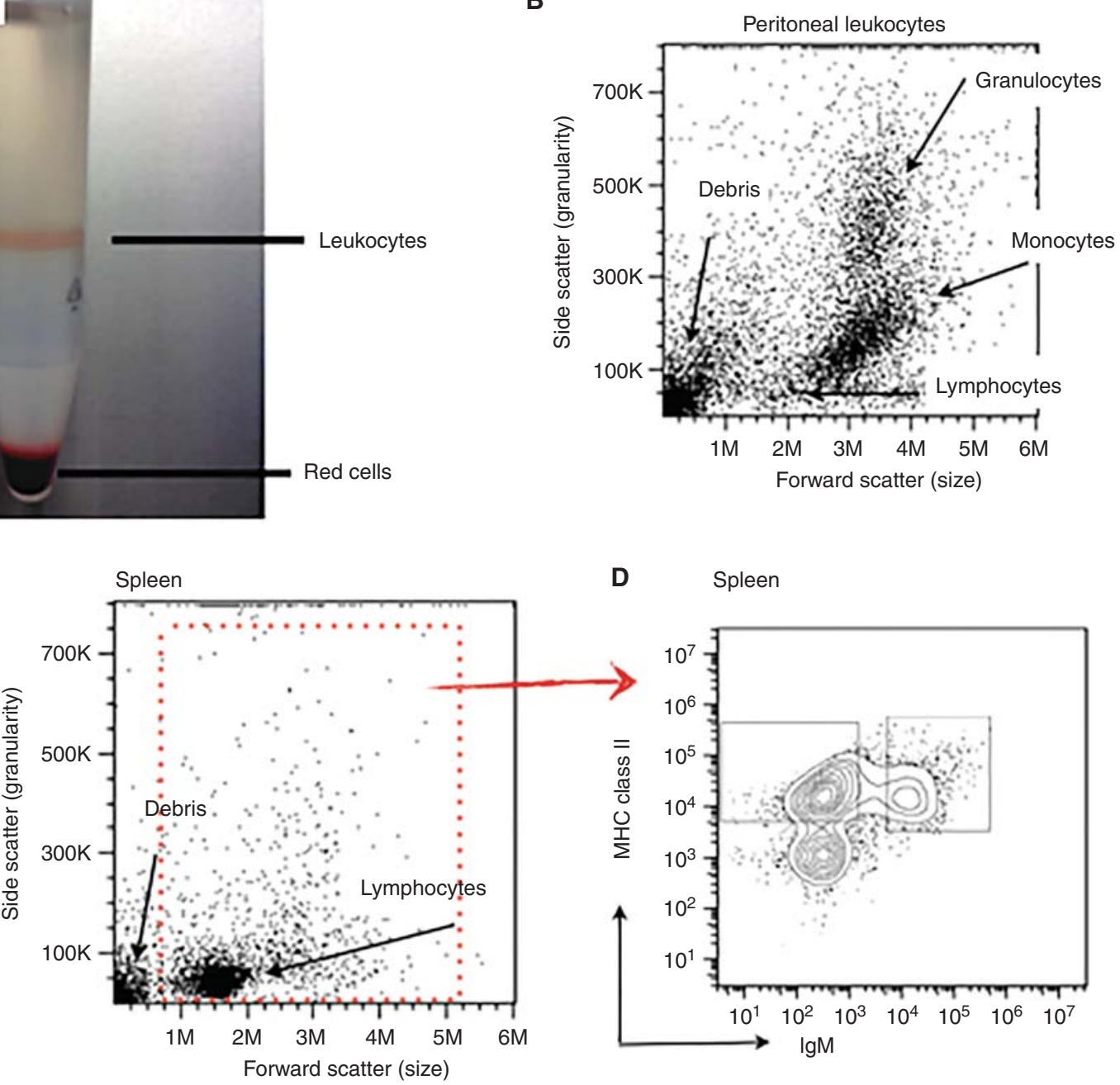

D Spleen

FIGURE 1. (A) Isolation of leukocytes from blood samples as described in Step 6. (B,C) Identification of different cell populations based on forward- and side-scatter characteristics. $(B)$, peritoneal leucocytes (Steps $1-2),(C)$ spleen cells (Steps 10-13). (D) Identification of specific cell populations based on fluorescence. Live (propidium iodine negative) spleen cells from $(C)$ stained with anti-lgM followed by goat-anti-mouse FITC and biotinylated anti-MHC class II primary antibody and APC conjugated streptavidin as described in Steps 19-36.

6. Collect the cloudy interface, which contains the leucocytes, using a 1-mL pipette and transfer to a 1.5-mL microcentrifuge tube (see Fig. 1A).

7. Pellet cells at $300 \mathrm{~g}$ for $5 \mathrm{~min}$ at $4^{\circ} \mathrm{C}$. Resuspend the pellet in $1 \mathrm{~mL}$ of APBS. Mix gently.

8. Repeat Step 7 twice.

9. Perform Step 2.

\section{Isolation of Leukocytes from Lymphoid Tissue}

An example of a scatter profile for spleen cells is shown in Figure 1C.

10. Harvest tissue.

Frogs, unlike mammals, do not have lymph nodes; the main lymphoid organ is the spleen. Large fractions of $T$ cells are also found in the thymus.

11. Place a 1 inch square-sized mesh into a $35 \times 10 \mathrm{~mm}$ Petri dish. Soak the mesh with APBS. Place the tissue in the middle of the mesh and place a second 1 inch square-sized mesh on top of the 


\section{Staining Procedure}

tissue. Using micro mashing tweezers push the cells through the mesh using repetitive horizontal movements. Once the tissue is disrupted tilt the dish $45^{\circ}$ and rinse with APBS. Collect the cell suspension and transfer to $1.5 \mathrm{~mL}$ microcentrifuge tubes.

12. Pellet the cells by centrifugation at $300 \mathrm{~g}$ for $5 \mathrm{~min}$ at $4^{\circ} \mathrm{C}$. Discard the supernatants. Resuspend the pellets in APBS and combine in a final volume of $1 \mathrm{~mL}$.

13. Perform Step 2.

To remove red blood cells from the sample, Percoll gradient separation (Steps 4-9) can be performed.

\section{Isolation of Leukocytes from Nonlymphoid Tissue}

14. Harvest the tissue of interest and rinse with APBS.

15. Cut the tissue into $1-2 \mathrm{~mm}$ pieces using a scalpel blade and place in a $15-\mathrm{mL}$ centrifuge tube with $5 \mathrm{~mL}$ of APBS.

16. Add an appropriate amount of enzyme(s), such as collagenase, diluted in APBS and incubate under conditions recommended by the enzyme manufacturer. Disperse cells by gently pipetting and filter through a cell strainer to remove clumps.

17. Pellet the cells by centrifugation at $300 \mathrm{~g}$ for $5 \mathrm{~min}$ at $4^{\circ} \mathrm{C}$. Discard the supernatant. Add $4 \mathrm{~mL}$ of APBS.

18. Perform Steps 4-9.

Prepare the following controls: (1) unstained cells; (2) cells incubated with an isotype control secondary antibody alone; (3) cells incubated with fluorochrome-conjugated streptavidin alone; and (4) fluorochromes minus one control, i.e., prepare samples that have a combination of all fluorochromes used in the experiment except one. Depending on the number of fluorochromes used, the number of fluorochromes minus one control will vary. For example, in a three color staining protocol with anti-CD8-FITC, anti-CD4-PE, and anti-CD3-APC, three fluorochromes minus one control are needed (1. anti-CD8-FITC and anti-CD4-PE; 2. anti-CD8-FITC and anti-CD3-APC; and 3. antiCD4-PE and anti-CD3-APC).

A schematic showing different staining procedures (i.e., indirect and direct staining) is shown in Figure 2.

19. Dilute cells in FCSB to $1 \times 106-1 \times 107$ cells $/ \mathrm{mL}$. Aliquot $100 \mu \mathrm{L}$ of cell suspension into each test and control FACS tube.

20. Add $100 \mu \mathrm{L}$ of hybridoma supernatant containing $50-100 \mu \mathrm{g} / \mathrm{mL}$ of the primary antibody. Mix gently.

21. Incubate on ice for $30 \mathrm{~min}$.

22. Pellet the cells by centrifugation at $300 \mathrm{~g}$ for $5 \mathrm{~min}$ at $4^{\circ} \mathrm{C}$. Discard the supernatant. Resuspend the cells gently in $1 \mathrm{~mL}$ of FCSB.

23. Repeat Step 22 but resuspend the cells in $100 \mu \mathrm{L}$ of FCSB.

24. Dilute the appropriate fluorochrome-labeled secondary antibody $1: 100(0.1-1 \mu \mathrm{g} / \mathrm{mL})$ in $100 \mu \mathrm{L}$ of FCSB. Add to the cell suspension. Incubate for $30 \mathrm{~min}$ on ice. Protect from light.

Titrate the secondary antibody to determine which dilution allows for the strongest specific signal with the least background.

25. Pellet the cells by centrifugation at $300 \mathrm{~g}$ for $5 \mathrm{~min}$ at $4^{\circ} \mathrm{C}$. Discard the supernatant. Resuspend the cells gently in $1 \mathrm{~mL}$ of FCSB.

26. Repeat Step 25 but resuspend cells in $100 \mu \mathrm{L}$ of FCSB. If single staining is performed, proceed to Step 36.

27. Biotinylate a primary antibody according to Mao (2010) and dilute to $1 \mu \mathrm{g} / \mathrm{mL}$ in FCSB. Add 100 $\mu \mathrm{L}$ of the diluted biotinylated antibody to the cells. 
E.-S. Edholm

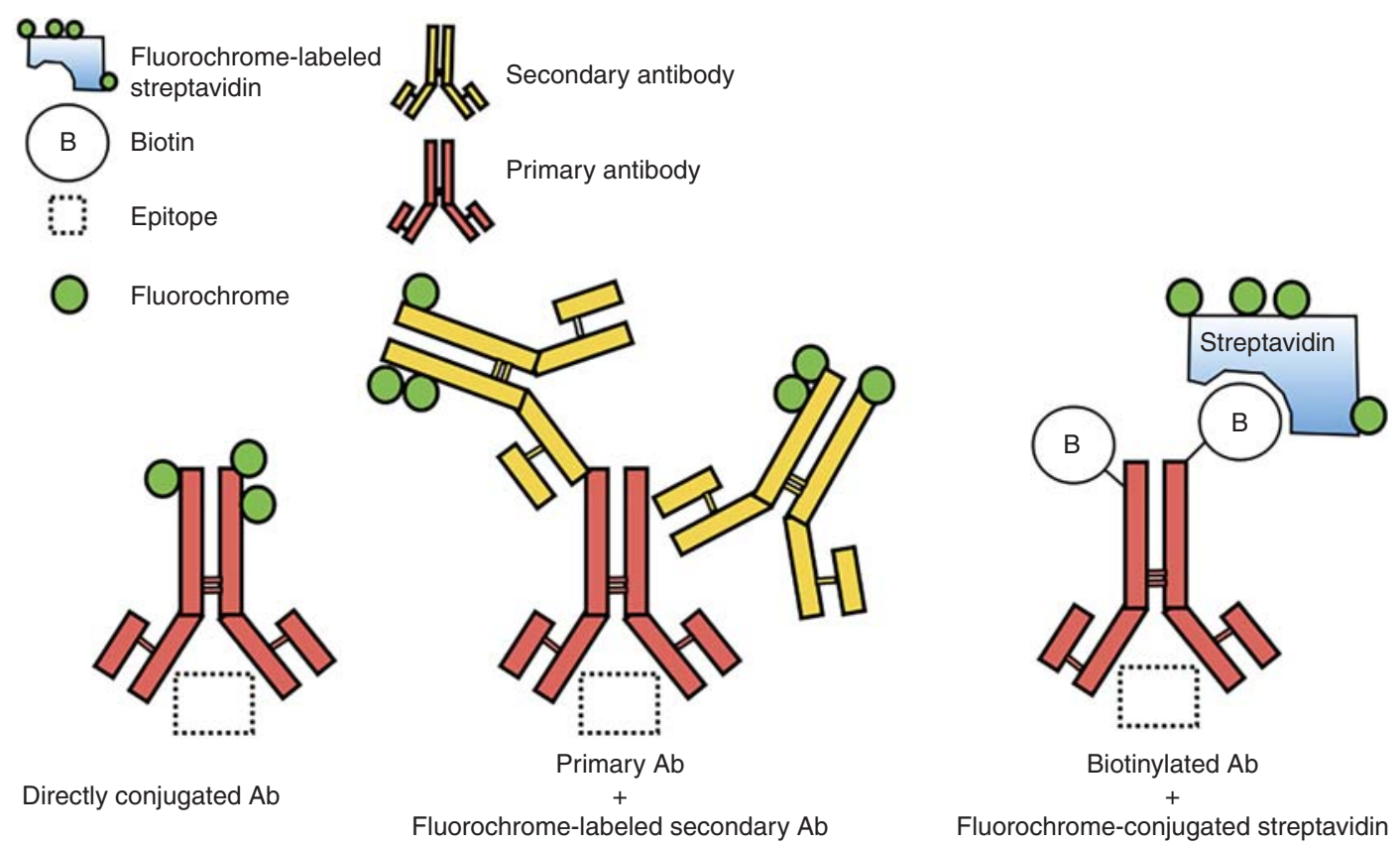

FIGURE 2. Schematic showing the different staining procedures described; indirect staining using primary and secondary antibodies, and direct staining using fluorochrome-conjugated primary antibodies and biotinylated primary antibodies.

Perform a titration curve to determine which dilution of the biotinylated primary antibody allows for the strongest specific signal with the least background.

28. Incubate on ice for $30 \mathrm{~min}$.

29. Pellet the cells by centrifugation at $300 \mathrm{~g}$ for $5 \mathrm{~min}$ at $4^{\circ} \mathrm{C}$. Discard the supernatant. Resuspend the cells gently in $1 \mathrm{~mL}$ of FCSB.

30. Repeat Step 29 but resuspend the cells in $100 \mu \mathrm{L}$ of FCSB.

31. Dilute fluorochrome-conjugated streptavidin $1 / 100$ in FCSB and add $100 \mu \mathrm{L}$ to the cells.

32. Incubate on ice for $30 \mathrm{~min}$.

33. Pellet the cells by centrifugation at $300 \mathrm{~g}$ for $5 \mathrm{~min}$ at $4^{\circ} \mathrm{C}$. Discard the supernatant. Resuspend the cells gently in $1 \mathrm{~mL}$ of FCSB.

34. Repeat Step 33 but resuspend the cells in $400 \mu \mathrm{L}$ of FCSB.

35. Just before analysis, add $0.5 \mu \mathrm{L}$ of propidium iodide to each sample.

36. Analyze samples by flow cytometry according to the instructions of the FACS instrument manufacturer.

An example showing MHC class II and IgM staining in spleen cells is shown in Figure 1D.

See Troubleshooting.

Problem (Step 36): Background caused by autofluorescence.

Solution: Use a fluorescent probe with high fluorescence intensity that emits light in the detection channel that is least effected by autofluorescence.

Problem (Step 36): Spectral overlaps.

Solution: Choose a combination of fluorochromes that have little to no spectral overlap. 
Problem (Step 36): Background caused by nonspecific antibody binding.

Solution: Increase the amount of BSA in the FCSB to $2 \%-5 \%$. Alternatively, incubate cells with $0.5 \%$ $X$. laevis serum for $30 \mathrm{~min}$ on ice before staining.

These procedures give a rapid and informative assessment of a large number of cells within a heterogeneous cell population. The combination of light scatter, which provides information about cell size and granularity, with specific cell-surface antigens is one of the most widely used applications of flow cytometry and provides valuable insight into the composition of cell populations. In addition, flow cytometry can be used to measure a long and constantly expanding list of parameters, including expression of intracellular antigens, total DNA content (for analysis of the cell cycle, cell kinetics, ploidy, etc.), phagocytosis (Grayfer and Robert 2014), apoptosis (De Jesús Andino et al. 2015), proliferation (Morales and Robert 2007), cytotoxicity assays (Haynes-Gilmore et al. 2014), and enzyme activity (Grayfer and Robert 2015). In addition, based on the same principles, fluorescent activated cell sorting is used to physically sort specific cell populations to purify populations of interest.

APBS

$25 \mathrm{~mL} \mathrm{H}_{2} \mathrm{O}$ (sterile; Merck)

$100 \mathrm{~mL}$ PBS (phosphate-buffered saline; Invitrogen)

In this recipe, $\mathrm{PBS}$ is adjusted to amphibian osmolarity $(225 \pm 5 \mathrm{mOsm} / \mathrm{L})$ by the addition of $\mathrm{H}_{2} \mathrm{O}$.

Flow Cytometry Staining Buffer (FCSB)

Add $10 \mathrm{~g}$ of bovine serum albumin to $700 \mathrm{~mL}$ of amphibian phosphate-buffered saline (APBS) $<$ R $>$. Stir well until dissolved. Add $50 \mu \mathrm{L}$ of $1 \mathrm{~m}$ sodium azide. (Sodium azide inhibits metabolic activity, so do not add sodium azide if recovering cell function is required-i.e., if cells are to be collected for cell culture or functional assays.) Adjust the volume to $1000 \mathrm{~mL}$ by adding additional APBS. Filter-sterilize through a $0.2-\mu \mathrm{m}$ filter and store at $4^{\circ} \mathrm{C}$.

\section{REFERENCES}

De Jesús Andino F, Grayfer L, Chen G, Chinchar VG, Edholm ES, Robert J. 2015. Characterization of Frog Virus 3 knockout mutants lacking putative virulence genes. Virology 485: 162-170.

Grayfer L. 2018. Elicitation of Xenopus laevis tadpole and adult frog peritoneal leukocytes. Cold Spring Harb Protoc doi:10.1101/pdb. prot097642.

Grayfer L, Robert J. 2014. Divergent antiviral roles of amphibian (Xenopus laevis) macrophages elicited by colony-stimulating factor- 1 and interleukin-34. J Leukoc Biol 96: 1143-1153.

Grayfer L, Robert J. 2015. Distinct functional roles of amphibian (Xenopus laevis) colony-stimulating factor-1- and interleukin-34-derived macrophages. J Leukoc Biol 98: 641-649.
Haynes-Gilmore N, Banach M, Edholm ES, Lord E, Robert J. 2014. A critical role of non-classical MHC in tumor immune evasion in the amphibian Xenopus model. Carcinogenesis 35: 1807-1813.

Mao SY. 2010. Biotinylation of antibodies. Methods Mol Biol 588: 49-52.

Morales HD, Robert J. 2007. Characterization of primary and memory CD8 T-cell responses against ranavirus (FV3) in Xenopus laevis. J Virol 81: $2240-2248$. 


\section{Flow Cytometric Analysis of Xenopus Immune Cells}

Eva-Stina Edholm

Cold Spring Harb Protoc; doi: 10.1101/pdb.prot097600 originally published online April 18, 2018

\begin{tabular}{|c|c|}
\hline $\begin{array}{l}\text { Email Alerting } \\
\text { Service }\end{array}$ & Receive free email alerts when new articles cite this article - click here. \\
\hline $\begin{array}{l}\text { Subject } \\
\text { Categories }\end{array}$ & $\begin{array}{l}\text { Browse articles on similar topics from Cold Spring Harbor Protocols. } \\
\text { Antibodies (119 articles) } \\
\text { Cell Biology, general (1382 articles) } \\
\text { Flow Cytometry (42 articles) } \\
\text { Immunology, general (128 articles) } \\
\text { Immunostaining (139 articles) } \\
\text { Immunostaining Cells (51 articles) } \\
\text { Immunostaining, general (94 articles) } \\
\text { Xenopus (210 articles) }\end{array}$ \\
\hline
\end{tabular}

